\title{
Social determinants of health and community health agent work*
}

\author{
Determinantes sociais de saúde e o trabalho do agente comunitário \\ Determinantes sociales de salud y el trabajo del agente comunitario
}

How to cite this article:

Broch D, Riquinho DL, Vieira LB, Ramos AR, Gasparin VA. Social determinants of health and community health agent work. Rev Esc Enferm USP. 2020;54:e03558. DOI: https://doi.org/10.1590/S1980-220X2018031403558

\section{Daiane Broch ${ }^{1}$ \\ Deise Lisboa Riquinho ${ }^{2}$ \\ Letícia Becker Vieira ${ }^{2}$ \\ iD Adriana Roese Ramos ${ }^{2}$ \\ D Vanessa Aparecida Gasparin ${ }^{1}$}

* Extracted from the dissertation: "Desafios na atuação dos agentes comunitários: compreensão da determinação social da saúde e das condições de trabalho", Universidade Federal do Rio Grande do Sul, 2017.

${ }^{1}$ Universidade Federal do Rio Grande do Sul, Programa de Pós-Graduação em Enfermagem, Porto Alegre, RS, Brazil.

${ }^{2}$ Universidade Federal do Rio Grande do Sul, Escola de Enfermagem, Porto Alegre, RS, Brazil.

\begin{abstract}
Objective: To understand the social determinants of health from the perspective of the work of community health agents. Method: A qualitative study conducted in a Health District Management in the city of Porto Alegre/Rio Grande do Sul, Brazil, through focus groups and semi-structured interviews with community health agents. The analysis took place through thematic categorization, and the social determinants of health were adopted as the analytical category. Results: Twenty-five (25) community health agent workers participated. Overlapping individual and collective themes emerged, from violence and drug trafficking to lack of sanitation, improperly disposed garbage, illiteracy and the health problems themselves. Conclusion: The study revealed a complex relationship between the work of community health agents and the social determinants of health, reinforcing the need for a cohesive health team with intersectoral initiatives to address the different demands of the territories which are worked and lived in.
\end{abstract}

\section{DESCRIPTORS}

Community Health Workers; Primary Health Care; Health Status Disparities; Working Conditions; Social Determinants of Health. 


\section{INTRODUCTION}

Social Determinants of Health (SDH) seek to mediate between multifaceted reality and social totality, considering a broad field in which health-disease processes are produced. The National Commission emphasizes that SDH encompass individual and collective factors, as well as the macrostructure which surrounds this individual ${ }^{(1)}$. The SDH concept is classically related to the conditions in which a person lives and works, including the "social, economic, cultural, ethnic/ racial, psychological, and behavioral factors which influence the occurrence of health problems and risk factors to the population"(2).

Healthy living emerges from this as a social phenomenon from the disparity in exposures and vulnerabilities, since the health-disease phenomenon, traditionally resulting from cause-effect, now considers the social, emotional, economic and spiritual dimensions of human beings ${ }^{(2)}$.

"Coping with such determinants requires professionals who articulate work in an intersectoral manner with the local reality of the territory, being able to establish effective care relationships", based on the bond and dialogue. Most of the time, "professionals are prepared to identify the social determinants of the health-disease process, but are not equipped to reflect and intervene on them" ${ }^{\prime(3)}$.

In this context, the Community Health Agent (CHA) plays a valuable role, as it is the central figure in the Family Health Strategy (FHS), which is characterized by providing care to the population belonging to a given territory, developed by multiprofessional teams based on local needs ${ }^{(4)}$. As an integral part of both the team and the community, the CHA is familiar with the demands of the population as they experience them periodically ${ }^{(5)}$, either through the monitoring of families assigned to their territory or through individual experience. In addition to registering and monitoring families, disseminating information for educational actions is also in the power of this worker ${ }^{(5)}$.

The work of this health professional has been marked by an expansion of practice and knowledge spaces since the implementation of the Unified Public Health System (SUS). The regulation and description of their attributes are listed in legislation and in a recent document in the National Policy of Primary Care (NPPC) $)^{(6)}$, "summarized in the activities of identifying risk situations; family and community orientation; and referral of identified cases and risk situations to other health team members based on a user-centered collaborative practice. Thus, the importance of continuing the CHA in planning and implementing health actions is recognized"(7) at the local level, as well as the remarkable role in the expansion and consolidation of Primary Health Care $(\mathrm{PHC})^{(7)}$.

These workers have diversified territories marked by accentuated vulnerabilities, "the work process is characterized by confronting social and environmental issues, such as drug trafficking, poverty, inefficient sanitation and the presence of garbage in the home"(8). Such issues generate important reflections on the health-disease process of the population.
This reinforces the need for human resources in public health prepared to act in confronting the reality of the prevailing care model in Brazil and its epidemiological and social context, marked by the growing involvement of chronic non-communicable diseases and paradoxically with the upsurge in transmissible diseases. Given this scenario, the relevance of the research is justified in view of the need to better understand the transversality of SDH in the daily work of the CHA, and how such determinants affect service users and the care provided from micro and macrosocial factors, with a view to interprofessional practices in the perspective of the CHAs.

In this sense, the objective is to understand the $\mathrm{SDH}$ from the perspective of the work of CHAs in the Health District Management of a municipality in southern Brazil.

\section{METHOD}

\section{Study Design}

A descriptive, exploratory study implementing a qualitative approach.

\section{Population}

The study population included the CHAs of the $28 \mathrm{FHS}$ teams present in the territory. The sample consisted of one agent per team, selected by convenience. The study scenario was the FHS located in three health districts in a state capital city in southern Brazil.

\section{SELECTION CRITERIA}

The inclusion criteria of the professionals were to be part of the service staff, regardless of employment bond, and working in the service for at least three months, while the exclusion criteria included any CHA who were away from work during the data collection period.

\section{Data collection}

Data collection took place from August 2015 to February 2016, initially through a focus group and later through semi-structured interviews in order to deepen the experiences reported by the informants. Both audio sessions were recorded using a digital device and later transcribed in full. Three focus groups were held with three meetings with each group, totaling nine meetings. Each meeting lasted approximately 2 hours.

Nine CHAs participated in the first Focus Group (FG); nine CHAs also started in the second, but with two dropouts; and ten started in the third FG, but there was one dropout, thus totaling 25 participants/FHS in the FG. Interviews were conducted with these participants in their workplaces after previous appointment, dealing with personal history, location, work process and health-illness-work trajectories.

The FG meetings took place at the Nursing School of the Universidade Federal do Rio Grande do Sul (UFRGS) during one shift of the week, previously agreed with the municipal manager. A University vehicle along with the presence of a researcher picked up and subsequently took participants to their workplaces, with both journeys totaling 2 hours. The 
focus group moderator was the project coordinator, and the observers were three previously trained research fellows. The following topics were addressed in the FG: after presentation of the participants and the research proposal, the discussion in the first meeting focused on "thinking about your work: what are the social and health problems of the communities and territories where you work"; in the second meeting, how do you "develop your work/orientation in considering a particular health problem and its context?" And in the third meeting, "to what extent does the knowledge you transmit come from your daily life and work experiences?”.

\section{DATA ANALYSIS AND PROCESSING}

Data analysis and processing occurred through thematic categorization composed of the pre-analysis, material exploration and treatment of the obtained results.

A scanning reading of the interviews was performed in the pre-analysis in order to obtain greater contact with the content. Then, the central meanings were captured with an affinity grouping of common ideas, in which the answers to the central question were cut out, chromatic coding of the findings was performed, and general concepts which guided the analysis were categorized.

The common ideas reflected in these clippings were then identified during the analysis of the material, and each interview was carefully examined in order to confirm that these ideas were expressed throughout the speeches of the subjects. The classification stage enabled constructing empirical categories with an emphasis on individual and collective aspects which overlap in the problem of SDH, being responsible for specifying the themes and theoretical concepts which guided the discovery and construction of meaning cores.

The final analysis consisted in processing the obtained results and their interpretation, trying to articulate the structured material of the testimonies with the specialized literature indexed in databases. The SDH were used as analytical category, since it based the knowledge of the studied object. NVivo software version 10 helped with material organization and word cloud formation.

\section{ETHICAL ASPECTS}

The interviews were identified by the letters CHA followed by the corresponding Arabic numeral in order to guarantee anonymity of the participants. The focus groups were identified as FG plus the group number (FG1, FG2 or FG3). The numerical classification took place at random from 1 to 25 , and the abbreviation FG and the meeting number for the focus groups. The study respected the prerogatives of Resolution 466/12 of the National Health Council, submitted and approved by the Research Ethics Committees of UFRGS under No. 1.009.554 and the Municipal Health Secretariat of Porto Alegre under No. 1.147.128; both approved in the year 2015.

\section{RESULTS}

Twenty-five (25) CHAs participated in the study, most of them female $(n=20)$, with a median of 45 years old, and
11 self-reported as black, 11 white and three brown as to their skin color/race. Regarding education, 16 participants had completed high school and/or technical training. The median time of acting as CHA was 2 years (minimum time of 8 months and maximum of 19 years).

The results are presented in two categories in light of the concept of SDH, in which one addresses the social conditions themselves such as violence and drug trafficking, and the other addresses more concrete aspects of life such as a lack of sanitation, garbage with improper disposal, illiteracy and health problems. The following illustrates the most frequent words in the participants' speeches by a word cloud:

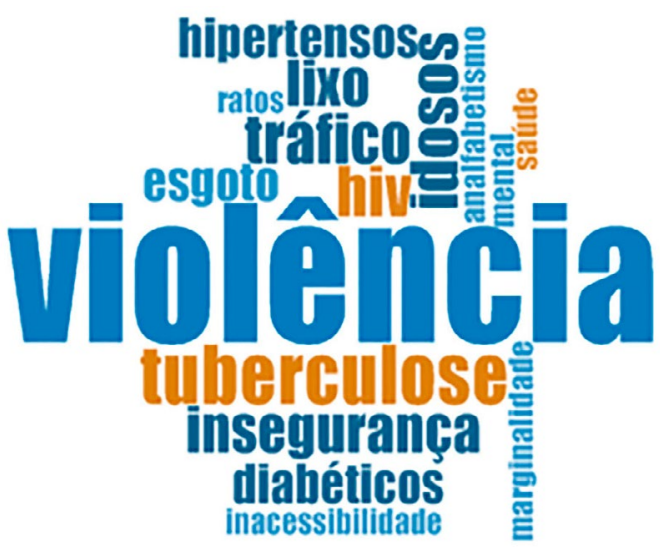

Figure 1 - Word cloud formed from frequency and meaning in statements about SDH in the CHA work process.

Source: Elaborated by the author using the NVivo software program.

VIOLENCE AND DRUG TRAFFICKING: "WE KNOW THE RISK OF A STRAY BULLET"

Violence was the main social problem that CHAs identified in the communities and territories where they work which affects their daily work and is a recurring fact, emphasizing that it frightens both the residents of the assigned area and the professionals. The CHA noted that the violence has considerably increased over the years, that they have been robbed and even threatened in activities outside the unit, as well as both inside and outside the FHS.

At my station it happened that a woman arrived outside her appointment, more than an hour late and said she was going in, so I said there are more people waiting before you. Then she came back with a machete and said she was going in and was going to be attended (FG 02).

The violence is always increasing, I'm very afraid of it (CHA 15).

The CHA voiced fear of walking in the streets of the neighborhoods. Work was impaired by fear, and home visits often ceased to be performed. The fear of providing care at home and even in the health unit was also expressed.

It's very dangerous, I'm afraid to walk on the street, I'm afraid to provide care, you have to take care here in this region (CHA 15).

Violence is a very serious problem here in the community (...) I'm very afraid of a stray bullet, afraid of being robbed (CHA 23).

Local drug trafficking was manifested as a driver of violence by the CHAs. 
I do my job, when they want something "look they shot at I don't know who, get a material to make a dressing", I go there and get the material (FG 02).

One thing that makes me very sad is to see teenagers, the children I saw in their mother's belly become traffickers. And then I see that my work went downbill (CHA 03).

The act of killing or dying sometimes presents itself as something commonplace in the community, worrying and destabilizing local professionals, who also have antagonistic feelings of fear, revolt and naturalization.

In this context, the work process suffers limitations due to the imposed conditions, there are situations in which it is only possible to perform health actions within the health units, with care being restricted only to users who can access the unit.

Before we could work on a form of prevention, we were respected as CHA, and health was respected. Once you could go into the alleys, we could do our job, but not today, if you see us and if we can't do what they want, we're bombarded (FG 01).

Violence is not only present due to population characteristics such as poverty and illiteracy, but these same characteristics point to greater abandonment of the State and civil society initiatives in developing school, musical and sports training projects, among others.

The statements showed that due to violence and marginality in the sense of being outside public policies, especially related to education, culture and leisure, many children and adolescents have already died in the community.

There is so much violence, many teenagers have died here, children who played there with my children (CHA 16).

It's scary, with each passing day the number of young people involved in crime increases (CHA 05).

Focus groups on the insecurity that CHA suffer daily were verbalized. This exposure to violence doubly affects $\mathrm{CHAs}$ because they work and live in a dangerous environment. Two CHAs also reported that delivery services such as pharmacy and food have become scarce at some points, even bus drivers take detours for fear of burglary.

Many people are terrified of the violence (...) there is shooting in the morning, afternoon and night (CHA 03).

Some CHAs pointed out that the expansion of drug trafficking accentuated violence in the community, exemplified by the following situation:

Early on their children are encouraged by their parents to pursue life in trafficking for the purpose of making money (FG 02).

\section{BASIC SANITATION, GARBAGE, ILLITERACY AND HEALTH PROBLEMS: "IT'S A CONSTANT JOB"}

The CHAs identified the lack of paved roads/sidewalks, urban pollution, especially the accumulation of garbage on the streets and poor sanitation with open sewage as factors which affect the daily lives of professionals and residents.

Reports have shown that pollution is a factor aggravated by garbage deposited on the streets. On days when there is no collection, dogs tear the bags and all the waste is scattered. Due to these conditions, the number of rats has considerably increased, increasing the chances of disease proliferation. As a group discussion, the $\mathrm{CHAs}$ pointed out that today there are few places where children have to play. A CHA explained that over the years some squares have turned into dumps.

Another aggravating factor present in the community is illiteracy. According to the CHA, users with this condition cannot organize their medicines, and they have to depend on the help of family, neighbors or health professionals.

Regarding the health problems present in the community, the CHAs cited Systemic Arterial Hypertension (SAH) and Diabetes Mellitus (DM) as prevalent diseases, especially in older adults, who are the main carriers of these chronic diseases. It has been reported that the number of older adults is high in most areas, which demands more time and attention from professionals due to their particularities such as impaired vision and hearing.

There are a lot of old people! And so we have to take care, check their medication and prescriptions, it's a constant job (FG 01).

It's an area with many older adults, I serve 110 older adults, I have 90 people who have hypertension, and a lot of them diabetes, the vast majority need help (FG 02 ).

Another concern shared by CHA was the difficult adherence of users to tuberculosis (TB) treatment due to the prolonged treatment (at least 6 months) which is necessary to cure it. Individuals often give up treatment or refuse to do the necessary therapy.

I think the big problem we have with tuberculosis is the treatment. Of these 3 years of work I only had one patient who did the full treatment (FG 02).

It was also pointed out by the CHAs that just like TB there is a significant increase in people infected with the Human Immunodeficiency Virus (HIV):

Often, along with tuberculosis the patients have HIV (FG 03).

Another problem in the community is the number of people with $H I V$, it's increasing (FG 02).

\section{DISCUSSION}

The construction of health and work as SDH is influenced by the increase of urban violence and the increase of infectious disease situations. Such contexts are challenging for professionals at the local level, especially the CHAs who experience this determination two-fold, as a resident of the territory and worker in these spaces. From this perspective, implementing policies which address these social, environmental and cultural dynamics demands a sensitive look at these configurations and their repercussions on such dynamics.

A study conducted in a Basic Family Health Unit located in the municipality of Aracati, Ceará state, showed that feelings such as anxiety, despair and distress became routine in the work process of $\mathrm{CHAs}$ due to community violence. Violence is understood as an event that causes disorders 
in health conditions, as well as professional performance, interfering with care provision ${ }^{(9)}$.

A systematic review analyzed hindering aspects which appear in the daily work of CHAs. Among the related problems, studies have shown the exposure of these workers to violence in regions of large urban centers, where organized crime and drug trafficking are prominent. The fact that they work and live in the same territory makes them "more vulnerable to situations of conflict compared to other FHS workers" ${ }^{\prime 7}$.

The CHAs pointed out that the health area was more respected and valued. However, professionals are currently prohibited by some traffickers from entering certain areas of the community. Crime and violence are two of the main problems experienced by the Brazilian population. The appropriation of space by traffickers is an exercise of power, in which factions use violence as a way of marking their borders ${ }^{(10)}$.

The consequences of drug trafficking trigger threats, assaults and aggressions which permeate the reality of health professionals' actions. The work of FHS professionals in the areas "where low-income families with little education, with precarious and socially unequal situations live" is challen$\operatorname{ging}^{(9)}$.

"Citizens live with the limitations and uncertainties imposed by violence. When exposed to conflicts involving the domain of trafficking"(9), users feel coerced in their homes, losing freedom within the community. This experience causes the residents' quality of life to be drastically affected $^{(11)}$. "In addition to interfering with socioeconomic and cultural issues"(9), it causes individuals to be subjected to daily robberies ${ }^{(12)}$ and the risk of being hit "by gunfire during disputes between rival territories" ${ }^{(9)}$.

The violence is closely linked with the social, economic and political structure. In several situations, it is necessary to adapt to the local reality for providing health care ${ }^{(13)}$, "which can pose numerous challenges for its effective promotion" ${ }^{(9)}$. According to a study conducted in a district on the outskirts of Belém, Pará state, the work performed by FHS professionals in community areas is unsafe and health care is often restricted only to users who go to the units ${ }^{(11)}$. In analyzing the situation of the nursing staff about mental suffering in the work process, it was evidenced that violence can cause "problems in professional performance, absenteeism and psychological changes" ${ }^{(9)}$, and this reality can be extended to $\mathrm{CHAs}^{(14)}$.

Inequalities in spaces for socialization, leisure and culture, the scarcity of basic sanitation and the lack of clean and running water in the slums and peripheries are factors which make the lives of families more arduous ${ }^{(15)}$. Uneven economic growth and rising poverty can influence crime rates in a given location, raising child mortality, drug abuse and disease overall ${ }^{(16)}$.

At this point, it is worth highlighting an articulation of the present study's findings and the hierarchy which constitutes the determinants existing between the factors which are more generally of a socioeconomic and political nature, and the mediations through which these factors affect the situation of individual and collective health ${ }^{(17)}$, whether of users, professionals or professional users, in the case of CHAs.

More broadly, it can be considered that understanding this complex of mediations, it becomes less difficult to understand the lack of correlation in the macroindicators of wealth of a given society; in other words, GDP does not determine the living and health conditions of the population. Moreover, mediation studies enable identifying interventions which may impact on reducing health inequities. From this perspective, it is essential in conceptual and methodological terms to distinguish between individual and group/ population-related SDHs, as the explanations do not cover the different realities ${ }^{(17)}$.

By examining SDH from a micro space, the influence of environmental factors such as secondary pollution of irregular deposit of solid waste can be seen. This deposit causes several "problems, such as environmental contamination, affecting the soil, water, groundwater and air. Among other factors, pollution is due to the decomposition process of organic matter, which generates slurry. This process highlights negative impacts on public health, attracting many harmful vectors to humans, who are in these areas in search of food or as a way of survival"(18).

Still analyzing this scenario, it is considered that this social and environmental vulnerability is the result of social processes and environmental changes, a combination of difficulties in working conditions, income, health and education. Such a combination of lack of healthy and safe housing and adequate sanitation makes certain population groups, especially the poorest, vulnerable to disasters ${ }^{(19)}$.

Another point to highlight in the SDH is linked to living conditions and poverty, in which illiteracy, the fragility of the social networks of older adults and chronic illness, which has proven to be highly prevalent in the aging situation, need to be strengthened in the social networks in the presence of family and/or state. However, given the diverse dynamics of family life, there is often no one responsible for this care, and many older people are abandoned in hospitals or nursing homes and face the precariousness of public investments to meet their needs.

Such reflection is necessary because the number of older people in Brazil has significantly increased over the years. The percentage of older adults in 2012 was $12.6 \%$, while it was $13 \%$ in 2013, totaling an average of 26.1 million. Just as there has been an increase in the number of older adults, the number of cases of non-communicable chronic diseases (NCDs) has been simultaneously growing, especially in this age group ${ }^{(20)}$. Hypertension and DM are cited as the most common conditions among NCDs, constituting the main causes of hospitalizations in the public health system. In addition, they are among the top five risk factors for mortality worldwide, as they increase the chances of developing other comorbidities ${ }^{(21)}$.

However, communicable diseases are still considered a problem of great impact on society. In Brazil, there is a demographic and epidemiological transition expressed by the concomitance of chronic diseases, infectious diseases and 
external causes ${ }^{(22)}$. TB is considered the second leading cause of death from infectious disease worldwide ${ }^{(23)}$. According to a study conducted in Minas Gerais, the main aggravating factors for the spread of TB are socioeconomic, environmental, and individual factors due to non-adherence to tuberculosis treatment, which makes it difficult to control this disease ${ }^{(24)}$.

In the reality of the municipality of this study, the average annual incidence of TB does not present a homogeneous distribution in the territory. The places with the highest incidence are the villages or slums, and the places with the lowest incidence are the neighborhoods with the best socioeconomic conditions ${ }^{(25)}$. The main reasons for users to abandon TB treatment are related to their low education level, lack of permanent residence and lack of financial resources for mobility. The research also described factors related to the health team as hindering factors in treating $\mathrm{TB}$, especially due to a deficient formation in the bond between professionals and the population, the absence of qualified listening, as well as a deficit in reception and follow-up ${ }^{(26)}$. The situation pointed out in TB demonstrates the different hierarchy of determinants in health, whether individual or in the health system.

In this perspective, TB has been one of the main factors which contributed to death in people with HIV, with a national growth of $9.8 \%$ in the incidence of TB/HIV co-infection $^{(27)}$. The city of Porto Alegre has stood out for its high rates of TB/HIV co-infection. According to epidemiological data, Porto Alegre has the highest TB/HIV coinfection rate in Brazil, with 47.8 cases per 100,000 inhabitants, and still leads the cases of TB incidence and AIDS prevalence in $\mathrm{Brazil}^{(28)}$.

The focus group discussions also alluded to the growing number of people with depression in the areas served by the $\mathrm{CHAs}$, demanding a close look from professionals to this rising scenario in the country. Depression is evidenced as one of the top ten causes of disability in the world, causing limitations to physical, personal and social functioning ${ }^{(29)}$.
Demand for mental health is complex, since the increase in cases has mainly been due to the daily problems that the population faces in its territory, such as situations of violence and drug trafficking, as well as the precarious socioeconomic condition which results in a high number of vulnerable families ${ }^{(30)}$. SDH are present in daily life operations and therefore need to be confronted by different social and political actors at the local, regional and national levels.

\section{CONCLUSION}

The study revealed the complex relationship between the work of the CHA and SDH, especially in the following aspects: presence of violence in the territory, drug trafficking, lack of sanitation, waste with improper disposal, illiteracy and presence of people living with chronic non-communicable and communicable diseases.

The experienced situations go hand-in-hand with the macrosocial problems, as many of the difficulties encountered are also found in other regions, cities and countries, not just representing a local reality. In this context, identifying and analyzing SDH can assist in establishing practices with the purpose of assisting the decision-making process, critically evaluating the health-disease process and redirecting care.

As a member of the interprofessional team, the CHA collaborates differently in the actions of promotion, prevention, investigation, diagnosis and recovery of the population's health. This role reinforces the need for a cohesive health team with intersectoral initiatives to address the different demands of the territories which worked and lived in. Given the changes in the NPPC, especially regarding the presence of CHAs on the FHS teams, there is a risk of setbacks in the PHC work mode, hiding the life realities which influence the health-disease processes.

RESUMO

Objetivo: Compreender os determinantes sociais de saúde a partir da perspectiva do trabalho dos agentes comunitários de saúde. Método: Pesquisa qualitativa, realizada em uma Gerência Distrital de Saúde, no município de Porto Alegre/Rio Grande do Sul, por meio de grupos focais e entrevistas semiestruturadas junto a agentes comunitários de saúde. A análise ocorreu por meio da categorização temática, e adotaram-se os determinantes sociais de saúde como categoria analítica. Resultados: Participaram 25 agentes comunitários de saúde. Emergiram temas de cunho individual e coletivo que se sobrepuseram, desde a violência e o tráfico de drogas à ausência de saneamento, lixo com descarte inadequado, analfabetismo e os problemas de saúde propriamente ditos. Conclusão: O estudo revelou a complexa relação entre o trabalho dos agentes comunitários de saúde e os determinantes sociais de saúde, reforçando a necessidade de uma equipe de saúde coesa, com iniciativas intersetoriais para contemplar as diferentes demandas do território vivido.

\section{DESCRITORES}

Agentes Comunitários de Saúde; Atenção Primária à Saúde; Disparidades nos Níveis de Saúde; Condições de Trabalho; Determinantes Sociais da Saúde.

\section{RESUMEN}

Objetivo: Comprender los determinantes sociales de salud desde el punto de vista del trabajo de los agentes comunitarios de salud. Método: Investigación cualitativa, llevada a cabo en una Gerencia Distrital de Salud, en el municipio de Porto Alegre/Río Grande do Sul, mediante grupos focales y entrevistas semiestructuradas junto a agentes comunitarios de salud. El análisis ocurrió mediante la categorización temática y fueron adoptados los determinantes sociales de salud como categoría analítica. Resultados: Participaron 25 agentes comunitarios de salud. Emergieron temas de cuño individual y colectivo que se sobrepusieron, desde la violencia y el tráfico de drogas hasta la ausencia de saneamiento, eliminación inadecuada de basura, analfabetismo y los problemas de salud propiamente dichos. Conclusión: El estudio desveló la compleja relación entre el trabajo de los agentes comunitarios de salud y los determinantes sociales de salud, haciendo hincapié en la necesidad de un equipo de salud cohesivo, con iniciativas intersectoriales para abarcar las distintas demandas del territorio vivido.

\section{DESCRIPTORES}

Agentes Comunitarios de Salud; Atención Primaria de Salud; Disparidades en el Estado de Salud; Condiciones de Trabajo; Determinantes Sociales de la Salud. 


\section{REFERENCES}

1. Albuquerque GSC, Silva MJS. On health, determinants of health and the social determination of health. Saúde Debate [Internet]. 2014 [cited 2018 Mar 28];38(103):953-65. Available from: http://www.scielo.br/pdf/sdeb/v38n103/0103-1104-sdeb-38-103-0953.pdf

2. Dalcin CB, Backes DS, Ineu Dotto J, Teixeira Souza MH, Moreschi C, Buscher A. Determinantes sociais de saúde que influenciam o processo de viver saudável em uma comunidade vulnerável. Rev Enferm UFPE On Line. 2016;10:e01607. DOI: http://dx.doi.org/0.5205/ reuol.9199-80250-1-SM1006201607

3. Pereira IC, Oliveira MAC. O trabalho do agente comunitário na promoção da saúde: revisão integrativa da literatura. Rev Bras Enferm [Internet]. 2013 [citado 2018 mar. 21];66(3):412-9. Disponível em: http://www.scielo.br/pdf/reben/v66n3/a17v66n3.pdf

4. Guanaes-Lorenzi C, Pinheiro RL. Is the value of Community Healthcare Agents in Brazil's Family Health Strategy receiving full recognition? Ciênc Saúde Coletiva [Internet]. 2016 [cited 2018 Mar 22];21(8):2537-46. Available from: http://www.scielo.br/pdf/csc/v21n8/en_14138123-csc-21-08-2537.pdf

5. Maciazeki-Gomes RC, Souza CD, Lissandra Baggio L, Wachs F. The work of the community health worker from the perspective of popular health education: possibilities and challenges. Ciênc Saúde Coletiva [Internet]. 2016 [cited 2018 May 28];21(5):1637-46. Available from: http://www.scielo.br/pdf/csc/v21n5/1413-8123-csc-21-05-1637.pdf

6. Brasil. Ministério da Saúde. Portaria n. 2.436, de 21 de setembro de 2017. Aprova a Política Nacional de Atenção Básica, estabelecendo a revisão de diretrizes para a organização da Atenção Básica, no âmbito do Sistema Único de Saúde (SUS) [Internet]. Brasília; 2017 [citado 2018 mar. 25]. Disponível em: http://www.brasilsus.com.br/images/portarias/setembro2017/dia22/portaria2436.pdf

7. Alonso CMC, Béguin PD, Duarte FJCM. Work of community health agents in the Family Health Strategy: meta-synthesis. Rev Saúde Pública. 2018;52:e00395. DOI: http://dx.doi.org/10.11606/s1518-8787.2018052000395

8. Simões A L, Freitas CM. Análise sobre condições de trabalho de Equipe de Saúde da Família, num contexto de vulnerabilidades, Manaus (AM). Saúde Debate [Internet]. 2016 [citado 2018 maio 28];40(109):47-58. Disponível em: http://www.scielo.br/pdf/sdeb/v40n109/01031104-sdeb-40-109-00047.pdf

9. Santos MS, Silva JG, Branco JGO. O enfrentamento à violência no âmbito da estratégia saúde da família: desafios para a atenção em saúde. Rev Bras Promoç Saúde [Internet]. 2017 [citado 2018 mar. 25];30(2):229-38. Disponível em: http://periodicos.unifor.br/RBPS/ article/viewFile/5895/pdf

10. Oliveira GR, Freitas AML, Bortolo CA, Pereira EC, Canela JN, Trindade KKLF, et al. O mapa das drogas em uma cidade do Norte de Minas Gerais. Rev Eletr Acervo Saúde [Internet]. 2018 [citado 2018 jun. 12];1(10):1171-6. Disponível em: https://www.acervosaude.com.br/ doc/REAS154.pdf

11. Polaro SHI, Gonçalves LHT, Alvarez AM. Nurses challenging violence in the scope of practice in the family health program. Texto Context Enferm. 2013;22(4):935-42:e00009. DOI: http://dx.doi.org/10.1590/S0104-07072013000400009

12. Ferreira VP, Silva MA, Neto CN, Neto GHF, Chaves CV, Bello RP. Prevalência e fatores associados à violência sofrida em mulheres encarceradas por tráfico de drogas no Estado de Pernambuco, Brasil: um estudo transversal. Ciênc Saúde Coletiva [Internet]. 2014 [citado 2018 jun. 10];19(7):2255-64. Disponível em: http://www.scielo.br/pdf/csc/v19n7/1413-8123-csc-19-07-02255.pdf

13. Larsen DA, Lane S, Jennings-Bey T, Haygood-El A, Brundage K, Rubinstein RA. Spatio-temporal patterns of gun violence in Syracuse, New York 2009-2015. PLoS One [Internet]. 2017 [cited 2018 May 6];12(3):1-10. Available from: https://www.ncbi.nlm.nih.gov/pmc/articles/ PMC5358737/

14. Vasconcelos SC, Souza SL, Sougey EB, Ribeiro ECO, Nascimento JJC, Formiga MB, et al. Nursing staff members mental's health and factors associated with the work process: an integrative review. Clin Pract Epidemiol Ment Health. 2016;12:167-76.

15. Pérez BC, Jardim MD. A participação de crianças nas políticas públicas: construção, prática e desafios. Pesqui Prát Psicossoc [Internet]. 2015 [citado 2018 maio 10];10(1):206-18. Disponível em: http://pepsic.bvsalud.org/scielo.php?script=sci_arttext\&pid =S1809-89082015000100017

16. Marques Junior K. A renda, desigualdade e criminalidade no Brasil: uma análise empírica Rev Econ Nordeste [Internet]. 2014 [citado 2018 jun. 18];45(1):34-46. Disponível em: https://ren.emnuvens.com.br/ren/article/view/62

17. Buss PM, Filho AP. A Saúde e seus determinantes sociais. Physis [Internet]. 2007 [citado 2018 jun. 20];17(1):77-93. Disponível em: http:// www.scielo.br/pdf/physis/v17n1/v17n1a06.pdf

18. Barboza MSM, Caixeta CK, Oliveira CA, Colares CJG. Gestão de resíduos sólidos do lixão da cidade de Pirenópolis. Rev Cient ANAP Brasil [Internet]. 2013 [citado 2018 maio 10]; 6(7):167-94. Disponível em: http://www.amigosdanatureza.org.br/publicacoes/index.php/ anap_brasil/article/view/429/456

19. Almeida ML, Peres AM, Ferreira MMF, Mantovani MF. Translation and adaptation of the Competencias Esenciales en Salud Pública para Ios recursos humanos en salud. Rev Latino Am Enfermagem. 2017;25:e2896. DOI: http://dx.doi.org/10.1590/1518-8345.1684.2896

20. Brasil. Ministério da Saúde; Secretaria de Atenção à Saúde Departamento de Atenção Básica. Estratégias para o cuidado da pessoa com doença crônica: diabetes mellitus [Internet]. Brasília; 2014 [citado 2018 mar. 22]. Disponível em: http://189.28.128.100/dab/docs/ portaldab/publicacoes/caderno_36.pdf

21. World Health Organization. Knowledge translation on ageing and health: a framework for policy development [Internet]. Geneva: WHO; 2012 [cited 2018 May 12]. Available from: http://www.who.int/ageing/publications/knowledge_translation_en.pdf

22. Mendes EV. As redes de atenção à saúde. Ciênc Saúde Coletiva [Internet]. 2010 [citado 2018 maio 22];15(5):2297-305. Disponível em: http://www.scielo.br/pdf/csc/v15n5/v15n5a05.pdf

23. Falzon D, Mirzayev F, Fraser Wares F, Baena IG, Zignol M, Linh N, et al. Multidrug resistant tuberculosis around the world: what progress has been made? Eur Respir J [Internet]. 2015 [cited 2018 May 10];45(1):150-60. Available from: https://www.ncbi.nlm.nih.gov/pmc/ articles/PMC4318660/ 
24. Neves JAJ, Machado AN, Santos TVC, Norberg AN, Ferreira RM, Freire NMS. Avaliação da tuberculose em pacientes da cidade de Manhuaçu, Minas Gerais, Brasil. Int Sci J [Internet]. 2014 [citado 2018 maio 30];1(29):125-37. Disponível em: http://www.interscienceplace.org/isp/ index.php/isp/article/view/285/282

25. Acosta LMW, Bassanesi SL. O paradoxo de Porto Alegre: os determinantes sociais e a incidência da tuberculose. Rev Bras Epidemiol Suppl DSS [Internet]. 2014 [citado 2018 jun. 20];88-101. Disponível em: http://www.scielo.br/pdf/rbepid/v17s2/pt_1415-790X-rbepid17-s2-00088.pdf

26. Araujo AS, Vieira SS, Junior BL. Fatores condicionantes ao abandono do tratamento da tuberculose relacionados ao usuário e à equipe de saúde. Cad Saúde Desenvolv [Internet]. 2017 [citado 2018 maio 26];10(6). Disponível em: https://www.uninter.com/cadernosuninter/ index.php/saudeedesenvolvimento/article/view/585/445

27. Santos DT, Garcia MC, Costa AANF, Pieri FM, Meier DAP, Albanese SPR, et al. Infecção latente por tuberculose entre pessoas com HIV/ AIDS, fatores associados e progressão para doença ativa em município no Sul do Brasil. Cad Saúde Pública [Internet]. 2017 [citado 2018 maio 28]; 33(8): 1-12. Disponível em: http://www.scielo.br/pdf/csp/v33n8/1678-4464-csp-33-08-e00050916.pdf

28. Porto Alegre. Secretaria Municipal de Saúde. Plano Municipal de Saúde de 2018 a 2021 [Internet]. Porto Alegre; 2017 [citado 2018 maio 28]. Disponível em: http://www2.portoalegre.rs.gov.br/sms/default.php?p_secao=927

29. Noronha Júnior MAG, Braga YA, Marques TG, Silva RT, Vieira SD, Coelho VAF, et al. Depressão em estudantes de medicina. Rev Med Minas Gerais. 2015;25:e50123. DOI: http://www.dx.doi.org/10.5935/2238-3182.20150123

30. Vieira AMB, Albuquerque EG, Pereira LA, Andrade IS. Percepção dos agentes comunitários de saúde acerca do acompanhamento aos usuários de saúde mental. SANARE [Internet]. 2017 [citado 2018 jun. 30];16(1):24-31. Disponível em: https://sanare.emnuvens.com.br/ sanare/article/view/1090/601 